\title{
Defective In Vitro Growth of the Hemopoietic Progenitor Cells in the Acquired Immunodeficiency Syndrome
}

\author{
Carmelo Carlo Stella, Amold Ganser, and Dieter Hoelzer \\ Department of Hematology, University of Frankfurt, Theodor-Stern-Kai 7, D-6000 Frankfurt 70, Federal Republic of Germany
}

\begin{abstract}
In addition to immunologic derangement, hematological abnormalities have been reported in the majority of patients with acquired immunodeficiency syndrome (AIDS). In this study 15 patients with AIDS or AIDS-related complex (ARC) were evaluated for the in vitro growth of hemopoietic progenitor cells. In all patients a significant reduction of growth (mean \pm SEM) of colony-forming unit-granulocyte, erythrocyte, macrophage, (megakaryocyte) (CFU-GEM) (1.2 \pm 0.3$)$, burst-forming unit-erythroid

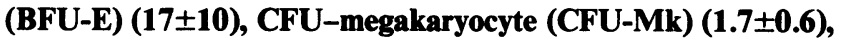
and CFU-granulocyte-macrophage (CFU-GM) (35 \pm 10$)$ was observed in comparison with normal controls.

Depletion of $T$ cells from the bone marrow before culture led to a significant increase in colony growth, which indicated an imbalance of the normally modulating $T$ cell subsets. This increase was reversed by readdition of autologous $T$ cells causing a decrease in colony growth to a degree, dependent on the T4 to T8 ratio.

A decreased number of hemopoietic progenitor cells and/or a defective modulation of progenitor cell growth, normally carried out by $T$ lymphocyte subsets, might be the cause of the hematological abnormalities in AIDS patients.
\end{abstract}

\section{Introduction}

The acquired immunodeficiency syndrome (AIDS) is a recently recognized disease caused by the human immunodeficiency virus (HIV), ${ }^{1}$ formerly termed T cell lymphotropic virus III (1) or lymphoadenopathy-associated virus (2). The hallmark of AIDS is depressed $\mathrm{T}$ cell immunity (3-5) owing to an infection of the helper/inducer T cell subset by the HIV (1). Among the immunological abnormalities reported in patients with AIDS are

Dr. C. C. Stella is on leave from the Department of Internal Medicine, University of Pavia, Italy. Address all correspondence to Dr. A. Ganser, Department of Hematology, University of Frankfurt, Theodor-SternKai 7, D-6000 Frankfurt 70, FRG.

Received for publication 12 March 1986 and in revised form 27 February 1987.

1. Abbreviations used in this paper: AET, 2-amino-ethylisothiouronium bromide; ARC, AIDS-related complex; BFU-E, burst-forming unit-erythroid; CFU-GEM, colony-forming unit-granulocyte, erythrocyte, macrophage, (megakaryocyte); CFU-GM, CFU-granulocyte-macrophage; CFU-MK, CFU-megakaryocyte; HIV, human immunodeficiency virus; IMDM, Iscove's modified Dulbecco's medium; MNC, mononuclear cells; PHA-LCM, phytohemagglutinin-leukocyte-conditioned medium; SRBC, sheep red blood cells; $\mathrm{T}^{+}$, autologous $\mathrm{T}$ cells; $\mathrm{T}^{-}, \mathrm{T}$ cell-depleted bone marrow cells.

J. Clin. Invest.

(c) The American Society for Clinical Investigation, Inc.

0021-9738/87/08/0286/08 $\$ 2.00$

Volume 80, August 1987, 286-293 diminished numbers $(6,7)$ and functions ( 8 ) of circulating helper/ inducer $T$ cells, reversals of the T4 to T8 ratios (7), production of soluble suppressor factors $(9,10)$, decreased expression of HLA-DR antigen on monocytes (11), and diminished production of interleukin 2 and other lymphokines $(12,13)$.

In addition to the derangement of the immune system, peripheral blood cytopenia of one or more hematological cell types has been noted in $\sim 60 \%$ of the patients (14-16), and also bone marrow changes such as increased cellularity and abnormalities in maturation of different hemopoietic lineages, as in myelodysplasia, have been observed (16-18).

The mechanisms responsible for the derangement of hemopoiesis in AIDS patients are still unknown. Although cytopenias in AIDS are sometimes associated with Coombs' test positivity (15) or the presence of anti-platelet antibodies $(16,19)$, the significance of these antibodies is not clear (4) and direct involvement of the hemopoietic progenitor cells might also be an important factor $(4,20)$.

The development of in vitro clonal assays for multipotent and committed hemopoietic progenitors has enhanced our understanding of the regulation of hemopoiesis and also of the interactions between accessory cells ( $T$ lymphocytes and macrophages) and hemopoietic progenitors $(21,22)$. Several studies support the notion that disturbances in the activation of regulation or in the expansion of $T$ cell subsets may result in hemopoietic failure (23). Furthermore, Leiderman et al. (20) found a reduction in the number of bone marrow-derived granulocytemacrophage progenitors (colony-forming unit-granulocytemacrophage [CFU-GM]) in patients with AIDS and the production of a factor inhibitory to normal progenitor cells.

It was the aim of the present study to establish the incidence of the multipotent hemopoietic progenitor cells (CFU-granulocyte, erythrocyte, monocyte [megakaryocyte] [CFU-GEM]) and of the committed progenitor cells (burst-forming unit-erythroid [BFU-E], CFU-megakaryocyte [CFU-Mk], and CFU$\mathrm{GM}$ ) in the bone marrow from patients with AIDS. Furthermore, the influence of $\mathrm{T}$ cell subsets on in vitro growth of hemopoietic progenitor cells was investigated by depleting the bone marrow of autologous $\mathrm{T}$ cells $\left(\mathrm{T}^{+}\right)$and replacing them before culture.

\section{Methods}

Patients. 15 patients who qualified according to the Centers for Disease Control (Atlanta, GA) case definition of AIDS and AIDS-related complex (ARC) (24) were studied. The clinical characteristics of the patients with AIDS are given in Table I. Patients had not received any cytotoxic or immuno-modifying therapy, e.g., with interferon, before being studied.

Blood and bone marrow samples. After informed consent bone marrow was obtained from patients by aspiration from the posterior iliac crest, at the time of bone marrow examination for clinical evaluation. Peripheral blood was simultaneously taken from 7 of the 15 patients reported herein. Normal bone marrow was obtained from hematologically healthy heterosexual male donors at the time of cardiac surgery and studied in parallel. To reduce contamination with peripheral blood, the volume of the aspirate was limited to $1.5-2.0 \mathrm{ml}$. 
Table I. Clinical Data of the Patients at the Time of the Study

\begin{tabular}{|c|c|c|c|c|c|c|c|c|c|c|}
\hline Patient & Sex & $\mathrm{Hb}$ & WBC & PMN & Ly & Mo & $\mathbf{P I}$ & $\mathrm{T4}^{+}$cells & $\mathrm{T}^{+}$cells & T4 to T8 ratio \\
\hline & & $g / d l$ & $\times 10^{\circ}$ & $\times 10^{\circ}$ & $\times 10^{\circ}$ & $\times 10^{\circ}$ & $\times 10^{\circ}$ & per $\mathrm{mm}^{3 *}$ & per $\mathrm{mm}^{3 \sharp}$ & \\
\hline $1^{8}$ & $\mathbf{M}$ & 16.6 & 3.6 & 1.88 & 2.16 & 0.14 & 222 & 681 & 1308 & 0.5 \\
\hline \multirow[t]{2}{*}{$2^{\text {s॥1 }}$} & $\mathbf{M}$ & 9.0 & 2.6 & 1.71 & 0.70 & 0.23 & 125 & 102 & 480 & 0.2 \\
\hline & & 8.1 & 2.7 & 1.79 & 0.76 & 0.05 & 145 & 133 & 339 & 0.4 \\
\hline $3^{1}$ & $\mathbf{M}$ & 10.5 & 3.0 & 2.0 & 0.45 & 0.18 & 283 & 45 & 207 & 0.2 \\
\hline $4^{\S}$ & $\mathbf{M}$ & 11.5 & 2.8 & 2.1 & 0.56 & 0.14 & 225 & 11 & 190 & 0.06 \\
\hline $5^{1}$ & $\mathbf{M}$ & 10.4 & 2.2 & 1.79 & 0.33 & 0.08 & 160 & 26 & 107 & 0.2 \\
\hline $6^{8}$ & $\mathbf{M}$ & 12.9 & 4.3 & 2.0 & 1.70 & 0.50 & 165 & 134 & 595 & 0.2 \\
\hline $7^{8}$ & $\mathbf{M}$ & 10.2 & 2.2 & 1.0 & 0.80 & 0.40 & 45 & 95 & 464 & 0.2 \\
\hline $8^{8}$ & $\mathbf{M}$ & 11.9 & 6.2 & 2.70 & 2.70 & 0.62 & 263 & 53 & 813 & 0.06 \\
\hline $9^{8}$ & $\mathbf{M}$ & 16.1 & 5.9 & 3.30 & 1.80 & 0.59 & 291 & 192 & 637 & 0.3 \\
\hline $10^{\prime}$ & $\mathbf{M}$ & 14.3 & 6.9 & 4.41 & 2.13 & 0.34 & 262 & 834 & 692 & 1.2 \\
\hline $11^{8}$ & $\mathbf{M}$ & 10.1 & 2.5 & 1.72 & 0.60 & 0.17 & 90 & 35 & 399 & 0.09 \\
\hline $12^{1}$ & $\mathbf{M}$ & 9.3 & 4.2 & 2.39 & 1.34 & 0.46 & 61 & 213 & 1082 & 0.2 \\
\hline $13^{8}$ & $\mathbf{M}$ & 11.2 & 2.5 & 1.47 & 0.80 & 0.22 & 105 & 114 & 499 & 0.2 \\
\hline $14^{8}$ & $\mathbf{M}$ & 15.0 & 6.6 & 4.49 & 1.65 & 0.46 & 229 & 407 & 700 & 0.6 \\
\hline $15^{1}$ & $\mathbf{M}$ & 11.7 & 2.4 & 0.98 & 1.03 & 0.14 & 174 & 154 & 637 & 0.2 \\
\hline
\end{tabular}

$\mathrm{Hb}$, hemoglobin; WBC, white blood cells; PMN, granulocytes; Ly, lymphocytes; Mo, monocytes; and Pl, platelets. * Normal range: 1,100-1,300. ${ }^{\ddagger}$ Normal range: $350-450$. 'Kaposi’s sarcoma. "This patient was studied on two separate occasions. 'AIDS-related complex.

Light-density mononuclear cells (MNC) were isolated by separation on a Ficoll-Hypaque gradient (density $1.077 \mathrm{~g} / \mathrm{ml}$ ) and centrifuged at $400 \mathrm{~g}$ for $40 \mathrm{~min}$ at $20^{\circ} \mathrm{C}$. Interface cells were washed three times in RPMI 1640 medium (GIBCO, Grand Island, NY) and resuspended in Iscove's modified Dulbecco's medium (IMDM) (Seromed, Berlin, FRG). The mean \pm SD counts of light-density MNC per milliliter of aspirate was $11.4 \times 10^{6} \pm 10.9 \times 10^{6}$ for patients with AIDS and $16.3 \times 10^{6} \pm 10.7$ $\times 10^{6}$ for the normal controls.

Depletion of $T$ lymphocytes. Suspensions of bone marrow and peripheral blood MNC $\left(5 \times 10^{6} / \mathrm{ml}\right)$ were depleted of T lymphocytes by rosetting with 2-amino-ethylisothiouronium bromide (AET) (Sigma Chemie GmbH München, Taufkirchen, FRG)-treated sheep red blood cells (SRBC) (GMN, Walldorf, FRG) $(25,26)$. Equal volumes of $2 \%$ AET-treated SRBC and marrow or peripheral blood MNC were mixed and incubated for $10 \mathrm{~min}$ at $37^{\circ} \mathrm{C}$. After centrifugation at $200 \mathrm{~g}$ for 5 min at room temperature, the pellet was incubated for $60 \mathrm{~min}$ at $4^{\circ} \mathrm{C}$. Then, the nonrosetting, $\mathrm{T}$ cell-depleted cell fraction was separated from rosetting, $T$ cell-enriched cell fraction by a second Ficoll-Hypaque gradient $(1.077 \mathrm{~g} / \mathrm{ml})$ centrifugation.

$T$ cell-depleted and $T$ cell-enriched cell fractions were treated with 0.83\% Tris-buffered ammonium chloride, $\mathrm{pH} 7.2$, washed twice in RPMI 1640 medium, and resuspended in IMDM. The viability of both T celldepleted and $\mathrm{T}$ cell-enriched cell fractions, as determined by Trypan blue dye exclusion, was always $>90 \%$.

Routinely, T cell-enriched blood cells were $85-98 \%$ OKT3 positive, whereas $T$ cell-depleted bone marrow cells $\left(\mathrm{T}^{-}\right)$were $91-98 \%$ OKT3 negative. Unseparated bone marrow light-density cells from patients with AIDS contained a mean of $22 \%$ OKT3-positive cells (range, 8-56\%), whereas in the normal controls the mean was 16\% (range, 6-30\%).

Depletion of adherent cells. Bone marrow light-density cells resuspended at a concentration of $2.5 \times 10^{6} / \mathrm{ml}$ in IMDM containing $5 \%$ human fresh-frozen plasma were incubated in plastic dishes (Greiner, Nurtingen, FRG) at $37^{\circ} \mathrm{C}$ in a $5 \% \mathrm{CO}_{2}$ atmosphere. After $60 \mathrm{~min}$ the non-adherent cells were transferred to new plastic dishes for a further 60-min-incubation step. Without further washings, the non-adherent cell suspensions were then plated in the colony assays at a concentration of $4 \%$ (vol/vol) to allow a direct comparison with the controls.

Monocyte depletion was checked with the MY-4 monoclonal antibody (27). Whereas $4-8 \%$ of the cells in the original cell suspensions were reactive with this antibody, $<0.5 \%$ of non-adherent cells were positive.

In vitro assays. The assay for CFU-GEM and committed progenitor cells has been previously described $(28,29)$. Briefly, $1 \times 10^{5}$ unseparated or $\mathrm{T}$ cell-depleted bone marrow light-density cells were plated in 35mm Petri dishes (Greiner) in 1-ml aliquots of IMDM containing $30 \%$ human fresh-frozen plasma from a single donor, 5-10\% medium conditioned by peripheral blood leukocytes (Phytohemagglutinin-leukocyteconditioned medium [PHA-LCM] $(30)$ in the presence of $1 \%$ phytohemagglutinin (PHA-HA 15) (Burroughs-Wellcome, Research Triangle Park, NC), $5 \times 10^{-5}$ M 2-mercaptoethanol (Sigma Chemie GmbH München), 1.0 U erythropoietin (Step III, Connaught Laboratories Ltd., Willowdale, Ontario), and $0.9 \%$ (wt/vol) methylcellulose. After incubation for $14 \mathrm{~d}$ at $37^{\circ} \mathrm{C}$ in a humidified atmosphere supplemented with $5 \%$ $\mathrm{CO}_{2}$, the cultures were examined with an inverted microscope. Four dishes were set up for each individual data point. Mixed colonies (CFUGEM), defined as containing at least erythroid and granulocytic cells by their in situ appearance; megakaryocytic colonies (CFU-Mk), defined as containing cells of varying size characterized by a translucent hyaline cytoplasm and highly refractile cytoplasmic border (31); erythroid bursts (BFU-E); and granulocyte-macrophage colonies (CFU-GM) were all scored from the same plates. Mixed colonies (CFU-GEM) could contain megakaryocytes, but this element was not especially quantitated in this study. Several batches of PHA-LCM were used. These were always produced by peripheral blood MNC from the same individual and tested for comparable stimulating activity. When tested retrospectively in our assay system, PHA-LCM stimulated in vitro colony formation of BFU$\mathrm{E}$ and CFU-GM in comparable numbers as $5 \%$ medium conditioned for $5 \mathrm{~d}$ by the cell line 5637 (32) or as $0.5 \mu \mathrm{g} / \mathrm{ml}$ recombinant human granulocyte-macrophage-colony-stimulating factor (33) (Behring-Werke AG, Marburg/Lahn, FRG), whereas higher numbers of CFU-GEM and CFU-Mk were regularly obtained with our preparations of PHA-LCM (unpublished observations). Similarly, a single donor was used for providing human plasma throughout the whole study. Since initial experiments did not demonstrate any difference between fresh and heat-inactivated human plasma on colony formation by AIDS-derived bone marrow cells, only fresh-frozen plasma was used in the present study.

According to the experimental design, populations of bone marrow $\mathrm{T}$ cells in two patients and/or peripheral blood $\mathrm{T}$ cells in seven patients, 
obtained by SRBC rosetting, were added back to cultures containing 1 $\times 10^{5}$ light-density $\mathrm{T}^{+}$and $\mathrm{T}^{-}$. In these co-culture experiments the ratio of $T^{-}$to $T$ cells was $1: 1$.

The expected number of CFU-GEM or committed progenitor cells per $1 \times 10^{5} \mathrm{~T}^{-}$was calculated by (34):

Expected CFU-GEM = (CFU-GEM $/ 10^{5}$ bone marrow cells)

$\times\{100 /(100-$ [percent $\mathrm{T}$ cells in bone marrow cells

- percent $\mathrm{T}$ cells in $\left.\mathrm{T}^{-}\right]$)\}.

In three experiments, $\mathrm{T}^{+}$from the peripheral blood were readded to $T^{-}$at ratios of $1: 5,1: 2$, and 1:1, respectively, and then plated.

In three experiments, bone marrow cells from normal controls and from patients with AIDS were resuspended at a concentration of 2.5 $\times 10^{6} / \mathrm{ml}$ in IMDM containing $5 \%$ human fresh-frozen plasma. Irradiation of the respective samples with 25 gray (Gy) was carried out at a dose rate of $0.67 \mathrm{~Gy} / \mathrm{min}$ using a Co-60 source before co-culture with non-irradiated cells.

Immunological characterization. The monoclonal antibodies OKT3, OKT4 and OKT8 (Ortho Pharmaceutical, Raritan, NJ) were employed to estimate the percentages of $T$ cells, $T$ cell subsets, and non- $T$ cells in the bone marrow and peripheral blood MNC before and after T cellcell depletion. The monoclonal antibody MY-4 (Coulter Diagnostics, Hialeah, FL) was employed to estimate the percentages of monocytes before and after adherent cell depletion.

The immunological characterization was performed according to Bross et al. (35). Briefly, the cells were transferred on to poly-L-lysin (Sigma Chemie GmbH München)-coated spots on glass slides. After 30 min the attached cells were fixed with glutaraldehyde $(0.05 \%$ in $0.1 \mathrm{M}$ phosphate buffer, $\mathrm{pH} \mathrm{7.4)}$ at $4^{\circ} \mathrm{C}$ for $5 \mathrm{~min}$ and washed with $0.3 \mathrm{M}$ glycine buffer for $10 \mathrm{~min}$. The cells were first incubated for $30 \mathrm{~min}$ at room temperature with the primary monoclonal antibody (final dilution 1:40 in Hanks' balanced salt solution (HBSS) (HBSS/0.1\% gelatin), and then goat-anti-mouse IgG conjugated with alkaline phosphatase (Sigma Chemie Gmbtl München), diluted 1:40 in HBSS/0.1\% gelatine, was applied for $20 \mathrm{~min}$. The slides were developed for alkaline phosphatase with naphthol AS-MX phosphate (Serva, Heidelberg, FRG) and Fast Red TR-salt (Serva) and then mounted in glycerine gelatin. The percentage of positive cells was determined by counting at least 200 cells per reaction area.

Statistical analysis. The Student's $t$ test for paired data was used to test for significance of changes in the number of progenitor cells grown from unseparated bone marrow, $\mathrm{T}^{-}$, and after addition of $\mathrm{T}$ cells. The Student's $t$ test for unpaired data was used to test for significant differences between hemopoietic progenitor cell growth from the patients and the control group. The linear correlation analysis was used to correlate the percentages of inhibition due to $T$ cell readdition and the $T 4$ to $T 8$ ratios.

\section{Results}

Baseline growth of hemopoietic progenitor cells. Initial experiments were carried out to determine the influence of cell concentration on in vitro colony formation of AIDS-derived bone marrow cells. As shown in Fig. 1, there is a linear relationship between the number of cells cultured per dish and the number of colonies grown. Similarly, the AIDS derived progenitor cells did not need a higher concentration of PHA-LCM than normal progenitor cells for colony formation.

Fig. 2 shows the number of multipotent and committed progenitor cells grown per $10^{5} \mathrm{MNC}$ from the bone marrow of 15 patients with AIDS as compared with normal controls $(n=24)$.

Baseline growth (mean \pm SEM) was significantly reduced for CFU-GEM (1.2 \pm 0.3 vs. $10.9 \pm 1.6, P<0.001)$, BFU-E $(17 \pm 10$ vs. $85 \pm 12, P<0.001)$, CFU-Mk $(1.7 \pm 0.6$ vs. $11.3 \pm 1.9, P$ $<0.001)$, and CFU-GM ( $35 \pm 10$ vs. $73 \pm 5, P<0.001)$.

Effect of $T$ cell depletion. To assess the effect of autologous

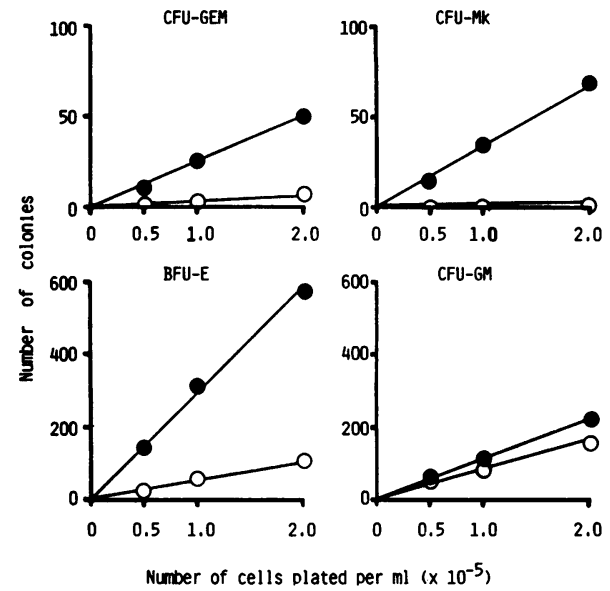

Figure 1. Correlation between the number of mononuclear bone marrow cells plated per milliliter and the number of colonies growing in culture (e, normal donor; 0 , patient with AIDS).

bone marrow $\mathrm{T}$ lymphocytes on hemopoietic progenitor cell growth, bone marrow cell suspensions from nine patients were depleted of T cells by rosetting with AET-treated SRBC. By T cell depletion, the percentage of $T$ cells could be reduced from 8-56\% down to 2-9\% OKT3-positive cells.

Table II shows the observed and expected numbers of colonies grown per $1 \times 10^{5} \mathrm{~T}^{-}$. The expected growth was calculated as described above.

T cell depletion increased significantly $(P<0.05)$ the growth of CFU-GEM to $3.4 \pm 1.3$ (mean \pm SEM). In 3 of the 10 experiments the observed CFU-GEM per $10^{5} \mathrm{~T}^{-}$were over 3, 7, and 15 times the expected values. In one of these cases the number of mixed colonies actually fell within the normal range. In four of the experiments $\mathrm{T}$ cell depletion resulted in a slight increase of CFU-GEM growth, whereas in three experiments no enhancement of colony growth was observed.

The growth of BFU-E (19.9 \pm 8.7$)$, CFU-Mk (5.6 \pm 2.2$)$, and CFU-GM (42.8 \pm 13.2$)$ per $10^{5} \mathrm{~T}^{-}$was also significantly enhanced ( $P<0.025, P<0.01$, and $P<0.025$, respectively) as compared with baseline growth.
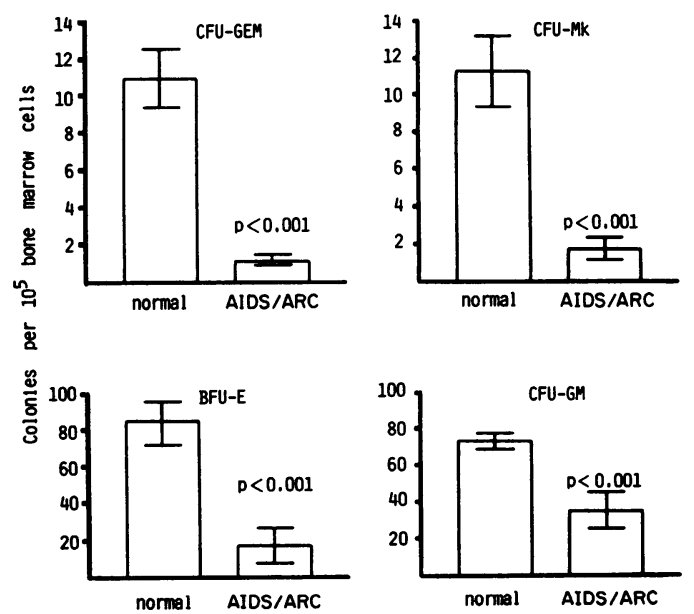

Figure 2. Incidence of the hemopoietic progenitor cells (CFU-GEM, CFU-Mk, BFU-E, and CFU-GM) of patients with AIDS/ARC ( $n$ $=15)$ and normal male controls $(n=24)$. Cells were cultured in quadruplicates at $1 \times 10^{5}$ cells $/ \mathrm{ml}$. 
Table II. Incidence of CFU-GEM, BFU-E, CFU-Mk, and CFU-GM per $10^{5} \mathrm{~T}^{-}$

\begin{tabular}{|c|c|c|c|c|c|c|c|c|}
\hline \multirow[b]{2}{*}{ Patient } & \multicolumn{2}{|c|}{ CFU-GEM/10 cells } & \multicolumn{2}{|c|}{ BFU-E $/ 10^{5}$ cells } & \multicolumn{2}{|c|}{ CFU-Mk/105 cells } & \multicolumn{2}{|c|}{ CFU-GM $/ 10^{5}$ cells } \\
\hline & Observed & Expected * & Observed & Expected & Observed & Expected & Observed & Expected \\
\hline 1 & $2.3 \pm 0.5^{\ddagger}$ & 2 & $20 \pm 4$ & 9 & $1 \pm 0.4$ & 1 & $19 \pm 2.3$ & 8 \\
\hline \multirow[t]{2}{*}{$2^{8}$} & $1 \pm 0$ & 0.3 & $4 \pm 1$ & 1 & $0.3 \pm 0.2$ & 0 & $22 \pm 1.1$ & 6 \\
\hline & 0 & 0 & $3 \pm 0.8$ & 1 & $0.3 \pm 0.2$ & 0.3 & $11 \pm 0.5$ & 7 \\
\hline 3 & $1 \pm 0.4$ & 1 & $4 \pm 1.1$ & 2 & $3 \pm 0.7$ & 1 & $14 \pm 1.6$ & 11 \\
\hline 4 & $1.5 \pm 0.3$ & 1 & $10 \pm 0$ & 6 & $4 \pm 0$ & 0.3 & $20 \pm 0.7$ & 14 \\
\hline 5 & $2 \pm 0.4$ & 2 & $8.5 \pm 1.2$ & 4 & $4 \pm 8$ & 2 & $19 \pm 0.6$ & 18 \\
\hline 6 & $7 \pm 0.7$ & 1 & $22.5 \pm 2.4$ & 3 & $10 \pm 0.9$ & 1 & $133 \pm 3.5$ & 58 \\
\hline 7 & $6 \pm 0.9$ & 0.4 & $33 \pm 3.7$ & 4 & $12 \pm 2.5$ & 1 & $79 \pm 2.9$ & 27 \\
\hline 8 & 0 & 0 & $2 \pm 0.4$ & 0.5 & 0 & 0 & $24 \pm 1.4$ & 12 \\
\hline 9 & $13 \pm 1.8$ & 4 & $93 \pm 5.7$ & 31 & $22 \pm 2.8$ & 9 & $88 \pm 1.5$ & 45 \\
\hline Control $(n=5)$ & $15 \pm 4$ & $17 \pm 5$ & $117 \pm 42$ & $120 \pm 38$ & $14.8 \pm 1.6$ & $16 \pm 4$ & $101 \pm 16$ & $115 \pm 1$ \\
\hline
\end{tabular}

* The expected numbers of progenitor cells was calculated by: (Progenitor cells $/ 10^{5}$ bone marrow cells) $\times 100 /(100-$ [percent $\mathrm{T}$ cells in bone marrow cells - percent $\mathrm{T}$ cells in $\left.\mathrm{T}^{-}\right]$). ${ }^{\ddagger}$ All values are means $\pm \mathrm{SEM}$ of four dishes. ${ }^{8}$ This patient was studied on two separate occasions.

It should be noted that in each patient, the increase in colony growth after $\mathrm{T}$ cell depletion was homogeneous with regard to the different classes of hemopoietic progenitor cells assayed, i.e., in each patient a high increase of CFU-GEM was related to a high increase of committed progenitors and vice versa.

In five control experiments using normal bone marrow, after $T$ cell depletion the observed growth (mean \pm SEM) for CFUGEM $(15 \pm 4, P>0.05)$ was $99 \%$ of expected; BFU-E (117 \pm 42 ,
$P>0.05), 98 \%$ of expected; CFU-Mk (14.8 $\pm 1.6, P>0.05)$, $109 \%$ of expected; and CFU-GM $(101 \pm 16, P>0.05), 89 \%$ of expected.

Effect of addition of autologous $T$ lymphocytes. To assess the effect of autologous $\mathrm{T}$ lymphocytes on hemopoietic progenitor cell growth, $1 \times 10^{5} \mathrm{~T}$ cells (effector cells) were added back to $1 \times 10^{5} \mathrm{~T}^{-}$(target cells). In preliminary experiments in which the effect of adding back blood $\mathrm{T}$ cells and marrow $\mathrm{T}$ cells was
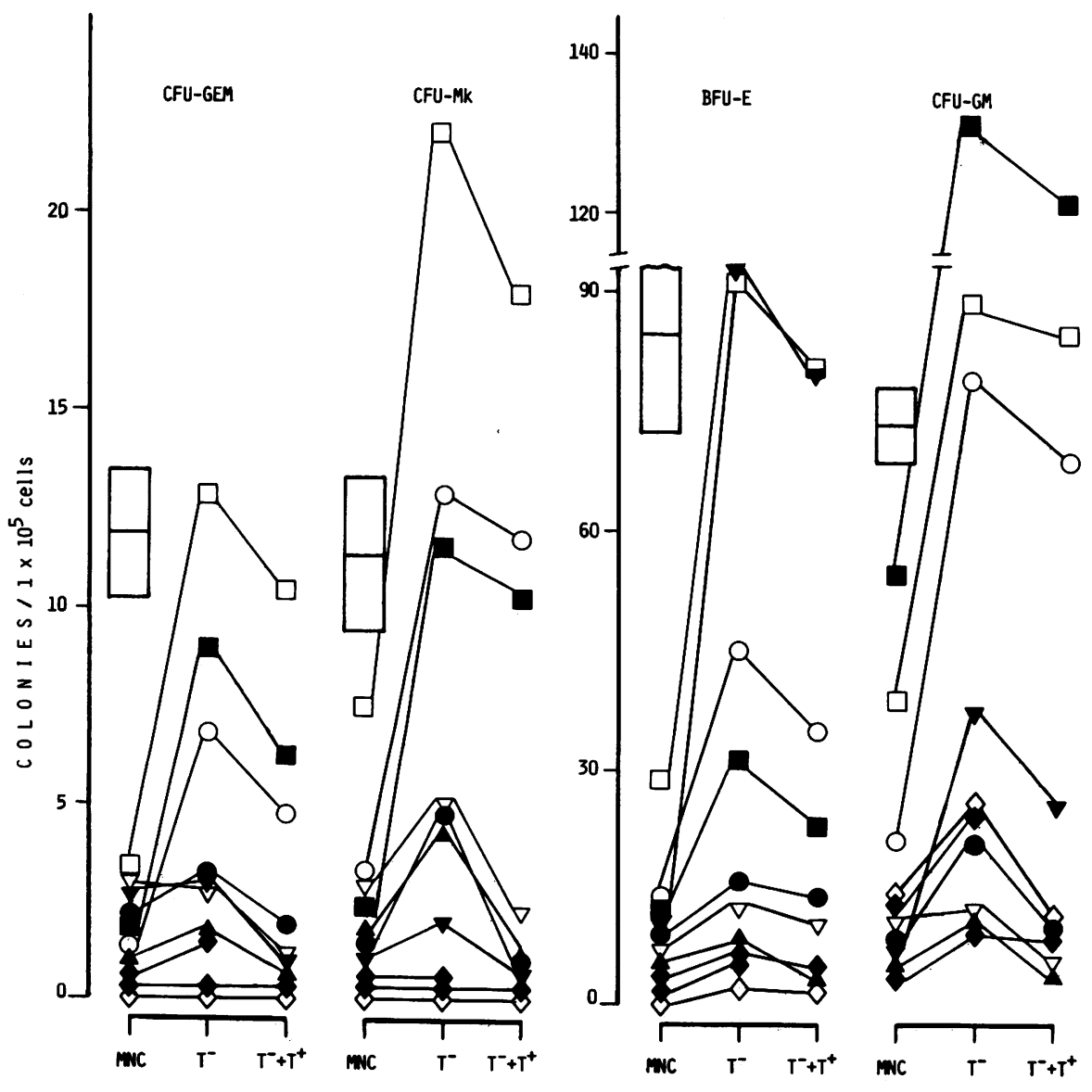

Figure 3. Hemopoietic progenitor cell growth (CFU-GEM, CFU-Mk, BFU-E, and CFU-GM) obtained from bone marrow $\mathrm{MNC}, \mathrm{T}^{-}$, and $\mathrm{T}^{-}+\mathrm{T}^{+}$in the patients studied. Bars represent the growth (mean \pm SEM) obtained in the control group per $10^{5}$ bone marrow MNC plated. One patient $(\bullet)$ was studied on two separate occasions. Blood-derived $T$ cells were used in $\square$, $\bullet, \diamond, \bullet, \diamond, \bullet$, and $\nabla$; bone marrow $T$ cells, in $\nabla$ and $\Delta$. 
compared, no particular difference was seen. Peripheral blood $T$ cells were added back in seven experiments, and bone marrow $\mathrm{T}$ cells, in two experiments.

The percentage of $\mathrm{T}$ cells in the enriched fractions used for $T$ cell replacements ranged from 85 to $98 \%$ OKT3-positive cells for peripheral blood, and from 57 to $85 \%$ OKT3-positive cells for bone marrow samples.

Co-culture of $\mathrm{T}^{+}$and $\mathrm{T}^{-}$resulted in a significant decrease of growth for CFU-GEM $(P<0.01)$, BFU-E $(P<0.01)$, CFU-Mk $(P<0.01)$, and CFU-GM $(P<0.001)$ (Fig. 3). The decrease of growth, as compared with $\mathrm{T}^{-}$, ranged from 18 to $85 \%$ (mean, 44\%) for CFU-GEM; from 11 to $44 \%$ (mean, $28 \%$ ), BFU-E; from 0 to $100 \%$ (mean, $38 \%$ ), CFU-Mk; and from 2 to $45 \%$ (mean, 20\%), CFU-GM.

In the two patients in whom $1 \times 10^{5} \mathrm{~T}$ cell-depleted target cells were co-cultured both with circulating or marrow $\mathrm{T}$ cells, the effect of $\mathrm{T}$ lymphocytes was similar. As shown in Table III, readdition of $T$ cells resulted in a dose-dependent reduction of colony formation.

The inhibitory effect of $\mathrm{T}^{+}$might have been dependent on the OKT4 to OKT8 ratio. Therefore, the percentage inhibition of hemopoietic progenitor cell growth was correlated to the OKT4 to OKT8 ratio in the T cells (Fig. 4). In two patients the inhibitory effect of both peripheral blood and bone marrow $T$ cells was studied in parallel. This correlation was statistically significant for CFU-GEM $(r=-0.937, P<0.001)$, BFU-E ( $r$ $=-0.690, P<0.05)$, CFU-Mk $(r=-0.972, P<0.001)$, and CFU-GM $(r=-0.702, P<0.05)$. No correlation was found

Table III. Effect of $T^{+}$on In Vitro Colony Formation of $T^{-}$ (Mean \pm SEM)

\begin{tabular}{|c|c|c|c|}
\hline & CFU-GEM & BFU-E & CFU-GM \\
\hline & \multicolumn{3}{|c|}{ Colonies per $10^{5}$ cells $\left(\mathrm{T}^{-}\right)$} \\
\hline \multicolumn{4}{|l|}{ Exp. I } \\
\hline $\mathbf{T}^{-}$ & $2 \pm 0$ & $90 \pm 10$ & $64 \pm 4$ \\
\hline $\mathrm{T}^{-}+\mathrm{T}^{+}(1: 0.2)$ & $2 \pm 1$ & $91 \pm 3$ & $44 \pm 4$ \\
\hline $\mathrm{T}^{-}+\mathrm{T}^{+}(1: 0.5)$ & $1 \pm 0$ & $84 \pm 1$ & $33 \pm 2$ \\
\hline $\mathrm{T}^{-}+\mathrm{T}^{+}(1: 1)$ & $1 \pm 0.5$ & $77 \pm 4$ & $25 \pm 1$ \\
\hline \multicolumn{4}{|l|}{ Exp. II } \\
\hline$T^{-}$ & $1.7 \pm 0.3$ & $99 \pm 3$ & $42 \pm 1$ \\
\hline $\mathrm{T}^{-}+\mathrm{T}^{+}(1: 0.2)$ & $1.0 \pm 0.5$ & $83 \pm 5$ & $37 \pm 1$ \\
\hline $\mathrm{T}^{-}+\mathrm{T}^{+}(1: 0.5)$ & $1.0 \pm 0.5$ & $76 \pm 7$ & $31 \pm 4$ \\
\hline $\mathrm{T}^{-}+\mathrm{T}^{+}(1: 1)$ & $0.3 \pm 0.3$ & $60 \pm 7$ & $23 \pm 2$ \\
\hline \multicolumn{4}{|l|}{ Exp. III } \\
\hline $\mathbf{T}^{-}$ & $7.3 \pm 1.5$ & $23 \pm 5$ & $66 \pm 7$ \\
\hline $\mathrm{T}^{-}+\mathrm{T}^{+}(1: 0.2)$ & $6.5 \pm 0.8$ & $21 \pm 3$ & $65 \pm 4$ \\
\hline $\mathrm{T}^{-}+\mathrm{T}^{+}(1: 0.5)$ & $6.0 \pm 0.4$ & $16 \pm 3$ & $56 \pm 4$ \\
\hline $\mathrm{T}^{-}+\mathrm{T}^{+}(1: 1)$ & $4.3 \pm 1.7$ & $12.5 \pm 3$ & $52 \pm 5$ \\
\hline
\end{tabular}

Exp. I. T-: 2\% OKT4, 1\% OKT8; $\mathrm{T}^{+}$: 9\% OKT4, 90\% OKT8. Exp. II. T-: $2 \%$ OKT4, 4\% OKT8; $\mathrm{T}^{+}: 15 \%$ OKT4, 64\% OKT8. Exp. III. T-: 3\% OKT4, 5\% OKT8; $\mathrm{T}^{+}: 12 \%$ OKT 4, 74\% OKT8. Correlation between the number of readded $T$ cells and the percentage inhibition: (Exp. I) $r=0.86$ for CFU-GEM, $P=0.14 ; r=0.98$ for BFU-E, $P=0.02 ; r=0.92$ for CFU-GM, $P=0.08$; (Exp. II) $r=0.94$ for CFU-GEM, $P=0.06 ; r=0.96$ for BFU-E, $P=0.04 ; r=0.99$ for CFU-GM, $P=0.01$; (Exp. III) $r=0.99$ for CFU-GEM, $P=0.01$; $r=0.98$ for BFU-E, $P=0.02 ; r=0.96$ for CFU-GM, $P=0.04$.
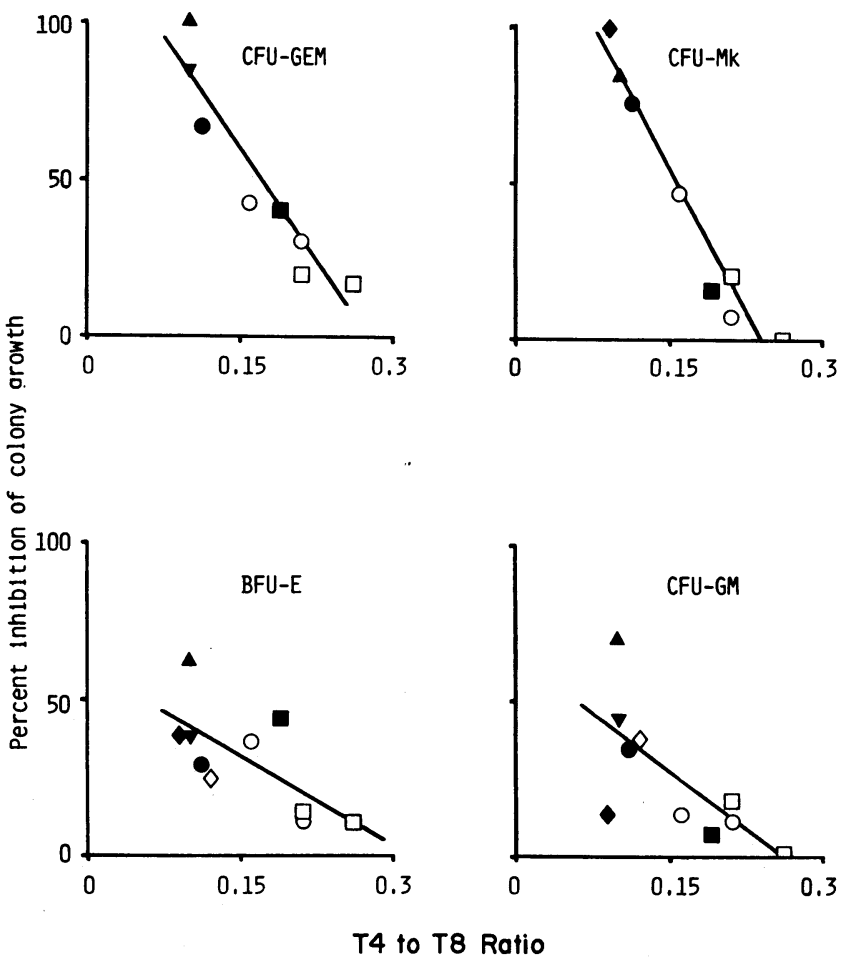

Figure 4. Correlation between the percentage inhibition of hemopoietic progenitor cell growth and the T4 to T8 ratio of $\mathrm{T}^{+}$added back to the T-. CFU-GEM $(n=8)$ : $r=-0.937, P<0.001$; CFU-Mk $(n=8)$ : $r=-0.972, P<0.001$; BFU-E $(n=10): r=-0.690, P<0.05$; CFUGM $(n=10): r=-0.702, P<0.05$. Each symbol represents one patient; the symbols correspond to those used in Fig. 3. In two patients $(\square, 0)$ the effect of both peripheral blood $T$ cells and bone marrow $T$ cells was analyzed.

between the percentage inhibition and the absolute number of OKT4- or OKT8-positive cells.

In five control experiments with normal marrow cells the $\mathrm{T}^{+}$failed to induce any change of growth (mean \pm SEM) for CFUGEM $(14 \pm 3, P>0.05)$, BFU-E $(114 \pm 41, P>0.05)$, CFU-Mk $(18 \pm 1.6, P>0.05)$, and CFU-GM $(93 \pm 18, P>0.05)$.

To analyze the influence of adherent cells on colony formation, the adherent cells were depleted from the cell suspension before culture in four experiments. Excluding enrichment of progenitor cells by the experimental design, no change in colony formation (mean \pm SEM) was observed (CFU-GEM, $0.7 \pm 0.4$ vs. $0.3 \pm 0.3$; BFU-E, $20 \pm 12$ vs. $16 \pm 4$; CFU-Mk, $0.7 \pm 0.7$ vs. $0 \pm 0$; CFU-GM, $20 \pm 4$ vs. $18 \pm 4$ ), similar to the findings in normal persons (unpublished observation).

To further investigate the cause of decreased colony formation in patients infected with HIV, co-culture of bone marrow cells from patients and from normal controls were performed. In two experiments with unirradiated cells, the number of colonies detected was consistent with the arithmetic sum of normal and AIDS-derived colonies (Table IV). Similarly, no evidence of an inhibition of normal progenitor cells by irradiated AIDSderived marrow cells or an ability of irradiated normal bone marrow cells to enhance colony formation by AIDS-derived progenitor cells was observed (Table V).

\section{Discussion}

Since peripheral blood cytopenia $(14,15,16)$ and myelodysplastic bone marrow changes (16) are frequently observed in 
Table IV. Co-Culture of Normal and AIDS Bone Marrow Cells (Mean \pm SEM)

\begin{tabular}{lcccc}
\hline & CFU-GEM & BFU-E & CFU-Mk & CFU-GM \\
\cline { 2 - 5 } & Per plate & & & \\
\hline Exp. I & & & & \\
$\quad$ Normal $\left(10^{5 *}\right)$ & $25 \pm 0.5$ & $313 \pm 17$ & $34 \pm 6$ & $114 \pm 6$ \\
AIDS $\left(10^{5}\right)$ & $3 \pm 0$ & $57 \pm 4$ & $0.5 \pm 0.5$ & $81 \pm 7$ \\
$\quad \begin{array}{l}\text { Normal and AIDS } \\
\quad\left(10^{5}+10^{5}\right)\end{array}$ & $20 \pm 2$ & $342 \pm 10$ & $35 \pm 0$ & $172 \pm 16$ \\
$\begin{array}{l}\text { Exp. II } \\
\text { Normal }\left(10^{5}\right)\end{array}$ & $21 \pm 0.5$ & $157 \pm 12$ & $33 \pm 1$ & $96 \pm 4$ \\
$\begin{array}{l}\text { AIDS }\left(10^{5}\right) \\
\text { Normal and AIDS } \\
\quad\left(10^{5}+10^{5}\right)\end{array}$ & $1.5 \pm 0.5$ & $93 \pm 6$ & 0 & $94 \pm 8$ \\
\hline
\end{tabular}

* Number of cells per plate (quadruplicate).

patients with AIDS the question was raised as to what extent the hemopoietic progenitor cells are involved in these patients. Therefore, an assay was used that not only allows the growth of CFU-GM (20), but also of the other committed progenitors, CFU-Mk and BFU-E, as well as of the multipotent CFUGEM (28).

A significant decrease in the incidence of all four types of progenitor cells was found in the patients studied, which by itself could explain the peripheral blood cytopenia similar to the findings in the myelodysplastic syndromes (36) and in aplastic anemia (37). The lack of a good correlation between the number of hemopoietic progenitor cells and the peripheral blood counts is a further indication that the hemopoietic system is capable to compensate for the deficiency of early hemopoietic progenitor cells under "normal" conditions, as previously shown in patients who have undergone highly aggressive chemotherapy (38) or allogeneic bone marrow transplantation (39). After cytostatic therapy for Kaposi's sarcoma or the use of folic acid antagonists in the treatment of opportunistic infections, patients with AIDS, however, develop prolonged cytopenia that might be due to the stress exerted on a defective progenitor cell system.

The estimation of the incidence of the progenitor cells in an aspirate from the posterior iliac crest only provides data on a limited volume of bone marrow at the site of aspiration, but does not allow to quantitate the total number of the progenitor cells in the body. Contamination with peripheral blood and se- lective loss of progenitor cells during the cell separation procedures might further lead to unpredictable variability in the number of marrow progenitors, but to some extent the variability was controlled by limiting the volume of the bone marrow aspirate (29) and by the absence of gross abnormalities in cellularity of the samples. Although the numbers of light-density MNC per milliliter aspirate were somewhat lower in the samples taken from the patients, this difference cannot account for the reduction in the in vitro colony formation, especially since there was no correlation between the number of colonies and the number of low-density cells per unit volume. However, the unresolved problem remains in that we cannot extend our data on the total volume of the hemopoietic tissue of patients with AIDS.

Since different mechanisms might lead to a reduction of in vitro growth of the hemopoietic progenitor cells, for instance stem-cell destruction, inhibition of colony growth by $\mathrm{T}$ cells or monocytes, or an imbalance between the $\mathrm{T}$ cell-helper and $\mathrm{T}$ cell-suppressor lymphocytes, different experimental approaches were used to study the extent to which colony growth was influenced by these mechanisms.

$T$ cell depletion resulted in a significant increase in colony growth not due to selective enrichment, which argues in favor of an inhibition by $T$ cells (37). Normally, no change in colony growth is observed after $\mathrm{T}$ cell depletion, which has previously been described (34) and also found in our control experiments. However, the colony growth reached normal values in only a minority of experiments. Explanations for this could be either incomplete $\mathrm{T}$ cell depletion leaving sufficient numbers of inhibitory $\mathrm{T}$ cells in culture, or the presence of still other inhibitory, but unidentified cells in the cell suspension. However, adherent cells can be largely excluded as a result of our experiments. Furthermore, the inhibitory effect is probably not due to the production of gamma-interferon within the 14-d culture, as has been discussed for aplastic anemia (40), since $T$ lymphocytes from patients with AIDS cannot produce this type of interferon (13).

Addition of $\mathrm{T}^{+}$to $\mathrm{T}^{-}$led to a decrease in colony growth, again the degree of which was dependent on the number of $T$ cells added. Since growth decrease was in addition inversely correlated to the $\mathrm{T} 4$ to $\mathrm{T} 8$ ratio, the balance between these two $\mathrm{T}$ cell subsets seems to have a pronounced effect on in vitro and probably in vivo growth of bone marrow hemopoietic progenitor cells (41). The disparity between the increase in colony formation after $T$ cell depletion, and the failure to inhibit normal progenitor cells by AIDS-derived bone marrow cells or to stimulate AIDSderived progenitor cells by normal bone marrow cells in the

Table V. Co-Culture of Bone Marrow Cells from Normal Persons and from Patients with AIDS/ARC*

\begin{tabular}{|c|c|c|c|c|}
\hline & CFU-GEM & BFU-E & CFU-Mk & CFU-GM \\
\hline 1. Normal $\left(10^{5}\right)$ & $5.1 \pm 0.3^{\ddagger}$ & $52 \pm 2$ & $4.9 \pm 0.2^{8}$ & $63 \pm 2$ \\
\hline 2. Normal $\left(10^{5}\right)+$ irradiated normal $\left(10^{5}\right)$ & $4.7 \pm 0.4$ & $53 \pm 6$ & $5.1 \pm 0.2$ & $57 \pm 2$ \\
\hline 3. Normal $\left(10^{5}\right)+$ irradiated AIDS $\left(10^{5}\right)$ & $4.3 \pm 0.2$ & $45 \pm 1$ & $4.4 \pm 0.2$ & $62 \pm 1$ \\
\hline 4. Normal $\left(10^{5}\right)+$ irradiated AIDS T depleted $\left(10^{5}\right)$ & $4.3 \pm 0.2$ & $44 \pm 1$ & $4.8 \pm 0.3$ & $59 \pm 1$ \\
\hline 5. $\operatorname{AIDS}\left(10^{5}\right)$ & $1.2 \pm 0.4$ & $29 \pm 11$ & $1.5 \pm 0.3$ & $73 \pm 27$ \\
\hline 6. $\operatorname{AIDS}\left(10^{5}\right)+$ irradiated AIDS $\left(10^{5}\right)$ & $2.0 \pm 0.6$ & $33 \pm 10$ & $2.3 \pm 0.8$ & $74 \pm 28$ \\
\hline
\end{tabular}

* Mean \pm S.E.M. from three experiments using bone marrow cells from three different normal donors and three different AIDS patients; respective cells were preirradiated with $25 \mathrm{~Gy}$. ${ }^{\ddagger}$ Significantly different from $5(P<0.025)$ and $6(P<0.05)$. Significantly different from 5 $(P<0.001)$ and $6(P<0.01)$. 
allogeneic co-culture experiments might be due to genetic restriction of the suppressive effect of the T cells (42).

Since HIV has been shown to infect many different cell types (43), it might well be that hemopoietic progenitor cells are similarly affected, which leads to a reduction in their total number. This would explain the lack of complete restoration of colony growth after the depletion of $\mathrm{T}$ cells. However, direct proof for it, with demonstration of virus sequences in stem cells or their progeny, is still lacking and will require further studies using enriched stem-cell populations.

In conclusion, our experiments strongly support the involvement of the bone marrow-derived hemopoietic progenitor cell compartments in AIDS, which results is myelodysplastic changes and cytopenia, and are probably being caused by direct stem-cell depletion and $\mathrm{T}$ cell imbalance. First experiments indicate similar defects in the hemopoietic progenitor cell compartments of the peripheral blood in patients with AIDS.

\section{Acknowledgments}

We gratefully appreciate the excellent technical assistance by Mesdames R. Geiger and M. Leonhardt.

This work was supported by the Bundesgesundheitsamt AIDS Research.

\section{References}

1. Gallo, R. C., S. Z. Salahuddin, M. Popovic, G. M. Shearer, M. Kaplan, B. F. Haynes, T. J. Palker, R. Redfield, J. Oleske, B. Safai, G. White, P. Foster, and P. D. Markham. 1984. Frequent detection and isolation of cytopathic retrovirus (HTLV-III) from patients with AIDS and at risk for AIDS. Science (Wash. DC). 224:500-503.

2. Barre-Sinoussi, F., J. C. Chermann, F. Rey, M. T. Nugeyre, S. Chamaret, J. Gruest, C. Daugmet, C. Axler-Blier, F. Vezinet-Brun, C. Rouzioux, W. Rozenbaum, and L. Montagnier. 1983. Isolation of a Tlymphotrophic retrivirus from a patient at risk for acquired immune deficiency syndrome (AIDS). Science (Wash. DC). 22:868-871.

3. Gottlieb, M. S., J. E. Groopman, W. M. Weinstein, J. L. Fahey, and R. Detels. 1983. The acquired immunodeficiency syndrome. Ann. Intern. Med. 99:208-220.

4. Siegal, F. P. 1984. Immune function and dysfunction in AIDS. Semin. Oncol. 11:29-39.

5. Fauci, A. S., H. Masur, E. P. Gelman, P. D. Markham, B. H. Hahn, and H. Clifford Lane. 1985. The acquired immunodeficiency syndrome: an update. Ann. Intern. Med. 102:800-813.

6. Rogers, M. F., D. M. Morens, J. A. Stewart, R. M. Kaminski, T. J. Spira, P. M. Feorino, S. A. Larsen, D. P. Francis, M. Wilson, L. Kaufman, and The Task Force of AIDS. 1983. National case-control study of Kaposi's sarcoma and pneumocystis carinii pneumonia in homosexual men. II. Laboratory results. Ann. Intern. Med. 99:151-158.

7. Fahey, J. L., H. Prince, M. Weaver, J. Groopman, B. Visscher, K. Schwartz, and R. Detels. 1984. Quantitative changes in T helper or T suppressor/cytotoxic lymphocyte subsets that distinguish acquired immune deficiency syndrome from other immune subset disorders. Am. J. Med. 76:95-100.

8. Clifford Lane, H., H. Masur, L. C. Edgar, G. Whalen, A. H. Rook, and A. S. Fauci. 1983. Abnormalities of B-cell activation and immunoregulation in patients with the acquired immune deficiency syndrome. N. Engl. J. Med. 309:453-458.

9. Cunningham-Rundles, S., M. A. Michelis, and H. Masur. 1983. Serum suppression of lymphocyte activation in vitro in acquired immunodeficiency disease. J. Clin. Immunol. 3:156-165.

10. Lawrence, J., A. B. Gottlieb, and H. G. Kunkel. 1983. Soluble suppressor factors in patients with acquired immune deficiency syndrome and its prodrome. Elaboration in vitro by T-lymphocyte-adherent cell interactions. J. Clin. Invest. 72:2072-2081.
11. Heagy, W., V. E. Kelley, T. B. Strom, K. Mayer, H. M. Shapiro, R. Mandel, and R. Finberg. 1984. Decreased expression of human class II antigens on monocytes from patients with acquired immune deficiency syndrome. Increased expression with interferon-gamma. J. Clin. Invest. 74:2089-2096.

12. Hauser, G. J., T. Bino, H. Rosenberg, V. Zakuth, E. Geller, and Z. Spirer. 1984. Interleukin-2 production and response to exogenous interleukin-2 in a patient with the acquired immune deficiency syndrome (AIDS). Clin. Exp. Immunol. 56:14-17.

13. Murray, H. W., B. Y. Rubin, H. Masur, and R. B. Roberts. 1984. Impaired production of lymphokines and immune (gamma) interferon in the acquired immunodeficiency syndrome. $N$. Engl. J. Med. 310:883890.

14. Spivak, J. L., S. E. Selonick, and T. C. Quinn. 1983. Acquired immune deficiency syndrome and pancytopenia. JAMA (J. Am. Med. Assoc.). 250:3084-3087.

15. Spivak, J. L., B. S. Bender, and T. C. Quinn. 1984. Hematologic abnormalities in the acquired immune deficiency syndrome. Am. J. Med. 77:224-228.

16. Schneider, D. R., and L. J. Picker. 1985. Myelodysplasia in the acquired immune deficiency syndrome. Am. J. Clin. Pathol. 84:144152.

17. Osborne, B. M., L. A. Guarda, and J. J. Butler. 1984. Bone marrow biopsies in patients with the acquired immunodeficiency syndrome. Hum. Pathol. 15:1048-1053.

18. Geller, S. A., R. Muller, M. L. Greenberg, and F. P. Siegal. 1985. Acquired immunodeficiency syndrome. Distinctive features of bone marrow biopsies. Arch. Pathol. Lab. Med. 109:138-141.

19. Stricker, R. B., D. I. Abrams, L. Corash, and M. A. Shuman. 1985. Target platelet antigen in homosexual men with immune thrombocytopenia. N. Engl. J. Med. 315:1375-1380.

20. Leiderman, I. Z., M. L. Greenberg, B. R. Adelsberg, and F. P. Siegal. 1984. Defective myelopoiesis in acquired immune deficiency syndrome (AIDS). In Acquired Immune Deficiency Syndrome, UCLA Symposium on Molecular and Cellular Biology. M. S. Gottlieb and J. E. Groopman, editors. A. R. Liss, New York. 281-289.

21. Cline, M. J., and D. W. Golde. 1979. Cellular interactions in hematopoiesis. Nature (Lond.). 277:177-181.

22. Lipton, J. M., and D. G. Nathan. 1985. Interactions between lymphocytes and macrophages in hematopoiesis. In Hematopoietic Stem Cells. D. W. Golde and F. Takaku, editors. Marcel Dekker, Inc., New York. 145-202.

23. Mangan, K. F. 1985. T-cell-mediated suppression of hematopoiesis. N. Engl. J. Med. 312:306-307.

24. Centers for Disease Control. 1982. Update on acquired immune deficiency syndrome (AIDS)-United States. Morbidity Mortality Weekly Report. 31:507-514.

25. Minden, M. D., R. N. Buick, and E. A. McCulloch. 1979. Separation of blast cell and T-lymphocyte progenitors in the blood of patients with acute myeloblastic leukemia. Blood. 54:186-195.

26. Kaplan, M. E., and C. Clark. 1974. An improved rosetting assay for detection of human T-lymphocyte. J. Immunol. Methods. 5:131139.

27. Griffin, J. D., R. J. Mayer, H. J. Weinstein, D. S. Rosenthal, F. S. Coral, R. P. Beveridge, and S. F. Schlossman. 1983. Surface marker analysis of acute myeloblastic leukemia: identification of differentiation associated phenotypes. Blood. 62:557-563.

28. Messner, H. A., N. Jamal, and C. Izaguirre. 1982. The growth of large megakaryocytic colonies from human bone marrow. J. Cell. Physiol. 1:45-51.

29. Ganser, A., and D. Hoelzer. 1986. Effect of intensified chemotherapy on the pluripotent haematopoietic progenitor cells CFU-GEMM in adult acute lymphoblastic leukemia. Br. J. Haematol. 64:169-178.

30. Aye, M. T., Y. Niho, T. E. Till, and E. A. McCulloch. 1974. Studies of leukemic cell populations in culture. Blood. 44:205-219.

31. Kimura, H., S. A. Burstein, D. Thorning, J. S. Powell, L. A. Harker, P. J. Fialkow, and J. W. Adamson. 1984. Human megakaryocytic 
progenitors (CFU-M) assayed in methylcellulose: physical characteristics and requirements for growth. J. Cell. Physiol. 118:87-96.

32. Welte, K., E. Platzer, L. Lu, J. L. Gabrilove, E. Levi, R. Mertelsmann, and M. A. S. Moore. 1985. Purification and biochemical characterization of human pluripotent hematopoietic colony stimulating factor. Proc. Natl. Acad. Sci. USA. 82:1526-1530.

33. Cantrell, M. A., D. Anderson, D. P. Cerretti, V. Price, K. McKereghan, R. J. Tushinski, D. Y. Mochizuki, A. Larsen, K. Grabstein, S. Gillis, and D. Cosman. 1985. Cloning, sequence, and expression of a human granulocyte/macrophage colony stimulating factor. Proc. Natl. Acad. Sci. USA. 82:6250-6254.

34. Levitt, L., T. J. Kipps, E. G. Engleman, and P. L. Greenberg. 1985. Human bone marrow and peripheral blood T-lymphocyte depletion: efficacy and effects of both T-cells and monocytes on growth of hematopoietic progenitors. Blood. 65:663-679.

35. Bross, K. J., G. A. Pangalis, C. G. Staatz, and K. G. Blume. 1978. Demonstration of cell surface antigens and their antibodies by peroxidase-antiperoxidase method. Transplantation (Baltimore). 25:331334.

36. Hoelzer, D., A. Ganser, and H. Heimpel. 1984. "Atypical" leukemias: preleukemia, smoldering leukemia and hypoplastic leukemia. Recent Results Cancer Res. 93:69-101.
37. Zoumbos, N. C., P. Gascon, J. Y. Djeu, S. R. Trost, and N. S. Young. 1985. Circulating activated suppressor T-lymphocytes in aplastic anemia. N. Engl. J. Med. 312:257-265.

38. Haworth, C., P. H. Morris-Jones, and N. G. Testa. 1982. Longterm bone marrow damage in children treated for ALL: evidence from in vitro colony assays (GM-CFC and CFU-F). Br. J. Cancer. 46:918923.

39. Li, S., R. Champlin, J. H. Fitchen, and R. P. Gale. 1984. Abnormalities of myeloid progenitor cells after "successful" bone marrow transplantation. J. Clin. Invest. 75:234-241.

40. Zoumbos, N. C., P. Gascon, J. Y. Djeu, and N. S. Young. 1985 Interferon is a mediator of hematopoietic suppression in aplastic anemia in vitro and possibly in vivo. Proc. Natl. Acad. Sci. USA. 82:188-194.

41. Geissler, D., L. Lu, E. Bruno, H. H. Yang, H. E. Broxmeyer, and $R$. Hoffman. 1986. The influence of T lymphocyte subsets and humoral factors on colony formation by human bone marrow and blood megakaryocyte progenitor cells in vitro. J. Immunol. 137:2508-2513.

42. Torok-Storb, B., and J. A. Hansen. 1982. Modulation of in vitro BFU-E growth by normal Ia-positive T cells is restricted by HLA-DR. Nature (Lond.). 298:473-474.

43. Wong-Staal, F., and R. C. Gallo. 1985. Human T-lymphotrophic retrovirus. Nature (Lond.). 317:395-403. 